ppi $201502 Z U 4645$

Esta publicación cientifica en formato digital es continuidad de la revista impresa ISSN-Versión Impresa 0798-1406 / ISSN-Versión on line 2542-3185Depósito legal pp

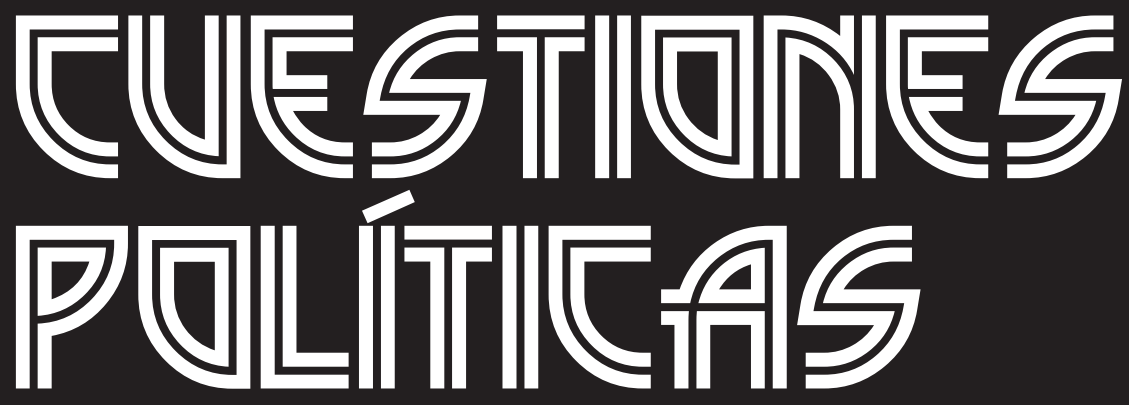

Instituto de Estudios Políticos y Derecho Público "Dr. Humberto J. La Roche' de la Facultad de Ciencias Jurídicas y Políticas de la Universidad del Zulia Maracaibo, Venezuela
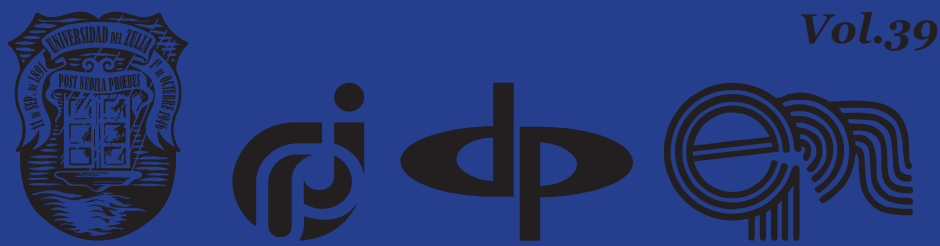


\title{
The Subsidiarity Principle and Legal and Economic Aspects of The Decentralization in Ukraine
}

\author{
DOI: https://doi.org/10.46398/cuestpol.3968.22
}

\author{
Sergiy Kvitka* \\ Yevgeniy Borodin** \\ Volodymyr Yemelyanov*** \\ Mykhäilo Moskalets $* * * *$ \\ Viktoriia Zubchenko ${ }^{* * * * *}$
}

\section{Abstract}

The research highlights the peculiarities of the decentralization of power in Ukraine in the political and legal implementation aspect of the principle of subsidiarity. The objective of the study was to determine compliance with the political and legal aspects of the decentralization process in Ukraine based on global standards of the use of the principle of subsidiarity, during the implementation of decentralization reform. The research methodology is based on the fact that the principle of subsidiarity is the main feature of the interaction of all levels of power. This premise is recognized in the European Charter of Local Self-Government and therefore means an urgent task in modern Ukraine. Financial decentralization, district consolidation, the creation of different but united territorial communities, changes in the administrativeterritorial structure, ensuring the capacities of communities, the provision of public services in accordance with national standards must be based on

* Doctor of Science in Public Administration, Professor, Dnipropetrovsk Regional Institute for Public Administration National Academy for Public Administration under the President of Ukraine, Ukraine. ORCID ID: https://orcid.org/oooo-ooo3-3786-9589. Email: skvitka14790@gmail.com

** Professor, Dnipropetrovsk Regional Institute for Public Administration National Academy for Public Administration under the President of Ukraine, Ukraine. ORCID ID: https://orcid.org/oooo-00027331-5981. Email: e.i.borodin@vidr.dp.ua

*** Doctor of Sciences in Public Administration, Professor of the Department of Public Management and Administration, Director of the Institute of Public Administration of the Petro Mohyla Black Sea National University, Ukraine. ORCID ID: https://orcid.org/oooo-0002-2995-8445. Email: d_idu@ ukr.net

**** PhD, Associate Professor in the Department of Public Administration and Law of Communal Institution of Higher Education «Dnipro Academy of Continuing Education» of Dnipropetrovsk Regional Council, Dnipro, Ukraine. ORCID ID: https://orcid.org/oooo-0oo3-3079-158X. Email: m_moskalets@ukr. net

***** PhD, Associated Professor, Department of Finance, Banking and Insurance, Bila Tserkva National Agrarian University, Ukraine. ORCID ID: https://orcid.org/oooo-0002-1292-1726. Email: vikazubchenko@ukr.net 
the principle of subsidiarity. The information gathered makes it possible to conclude that the principle of subsidiarity is a barrier to the overly profound centralization of the state body and the separation of power.

Keywords: subsidiarity; political and administrative decentralization; deconcentration of power; local self-government; Ukraine.

\section{El principio de subsidiariedad y los aspectos legales y económicos de la descentralización en Ucrania}

\section{Resumen}

La investigación da cuenta de las peculiaridades de la descentralización del poder en Ucrania en el aspecto de la implementación política y legal del principio de subsidiariedad. El objetivo del estudio fue determinar el cumplimiento de los aspectos políticos y legales del proceso de descentralización en Ucrania con base a los estándares mundiales del uso del principio de subsidiariedad, durante la realización de la reforma de descentralización. La metodología de investigación se basa en el hecho de que el principio de subsidiariedad es la característica principal de la interacción de todos los niveles de poder. Esta premisa es reconocida en la Carta europea de autogobierno local y significa, en consecuencia, una tarea urgente en la Ucrania moderna. La descentralización financiera, la consolidación de distritos, la creación de comunidades territoriales diferentes pero unidas, los cambios en la estructura administrativoterritorial, el aseguramiento de las capacidades de las comunidades, la prestación de servicios públicos de acuerdo con los estándares nacionales debe fundarse en el principio de subsidiariedad. La información recabada permite concluir que, el principio de subsidiariedad es una barrera para la centralización demasiado profunda del organismo estatal y la separación del poder.

Palabras clave: subsidiariedad; descentralización política y administrativa; desconcentración del poder; autogobierno local; Ucrania.

\section{Introduction}

In conditions of the digital transformation, the decentralization in Ukraine has acquired the new significance and importance as a process that leads the country to the principles of interaction between the state and society, recognized in Europe. The main political and legal aspect of this 
movement is the interaction of the state with another form of the public power - local self-government. Although the decentralization covers a very wide range of public relations with other spheres of society (such as business, culture, science, education, etc.), but the definition of the activities coordination principles of two most important power structures is the most pressing issue of Ukrainian politics and law enforcement. In this regard, one of the main European principles of the interaction between central and local government is the principle of subsidiarity.

The necessity for its practical implementation in Ukraine in order to fulfil the tasks of the European integration has been recognized widely by experts. However, at the political level, the term "subsidiarity" is used rarely, as in some cases it is associated with the federalization. The discrepancy between the objective meaning of the subsidiarity principle and its subjective perception by political forces requires more detailed analysis and even its promotion among civil servants and the municipal community (Kvitka, 2015).

\section{Literature review}

In recent decades, a lot of researches on political and legal issues of regional policy and local self-government were conducted. Many reference books and statistical collections have been published (Decentralization in Ukraine, 2020). However, a little attention is paid directly to the problem of applying the subsidiarity principle in the Ukrainian context, especially in the context of the digitalization. Most of materials are based on the European experience and were prepared with the support of international organizations.

First, they explain the importance of the subsidiarity principle, its role for Ukraine's European integration. But these publications provide only general remarks on the specifics of its use in Ukraine. As for specific studies, most of which are conducted on a grant basis, in almost all of them the decentralization and the subsidiarity are offered as the main recipes for overcoming the existing socio-economic problems in Ukraine (Hrubas, 2015). By our opinion, during the last years the best research on these issues have been conducted in the framework of Ukrainian-Canadian projects (MLED, 2020).

In these researches the question of the existence of restrictions on the implementation of the subsidiarity have been raised, especially, for local budgets and local economic development. Despite the rather big amount of publications, the task of defining the clearer criteria and mechanisms for implementing the subsidiarity principle in the everyday work of public administration in Ukraine is still urgent. The biggest problem remains the ambiguity of national standards of public (administrative, communal, 
etc.) services, which of them should be provided on the territory of the country. The influence of digital transformation on the peculiarities of the subsidiarity principle's introduction and political and legal aspects of this process are ignored by scientists (Batanov et al., 2014).

The aim of the study is to determine the political and legal aspects of the subsidiarity principle's introduction during the implementation of the decentralization reform in Ukraine in the context of the digital transformation.

\section{Results}

Subsidiarity (from the Latin Subsidiaries - auxiliary) is the organizational and legal principle, according to which tasks should be solved at the lowest, smallest or the most remoted from the centre level, at which their solution is possible and effective. The idea of the subsidiarity is akin to the decentralization. In the context of decentralization and expansion of the powers of territorial communities, the development of territories takes place, including the creation of conditions for attracting investments in the development of the tourism industry and other spheres of the economy (Koval et al., 2018; Koval et al., 2019; Popova et al., 2020; Yankovyi et al., 2020).

This principle has become a part of the European Union law as one of the main mechanisms to deter the excessive centralization. The very principle of the subsidiarity goes back to the ideas of Plato and Aristotle, as well as to the medieval city law. In Catholic social teaching, this concept became part of the official doctrine after the publication of the encyclical "Rerum Novarum" (1891) by Pope Leo XIII. The initial purpose of the principle was to resolve the conflict between the individual and society, which would avoid the extremes of both individualism and collectivism (Noyhauz, 2005). A further contribution to the theory was made by the encyclical "Quadragesimo Anno" (1931) by Pope Pius XI, where the concept was called "subsidiarity". In particular, it says:

The basic principle of social philosophy, established and unchanged, is that no one should take away from individuals and transfer to the society the opportunities that they can do by their own initiative and efforts. Hence, at the same time the transfer of those functions that can be provided and implemented by the lower and subordinate structures to a larger and more complex community will be injective, grave sin and will become the violation of the proper politics. Since any social activity, by its nature, should serve as a means of helping members of social education, it should never destroy or absorb them (individuality) (Noyhauz, 2005). 
According to the principle of the subsidiarity, the government should be as close as possible to the citizens. The state should take the initiative only in those issues where the capabilities of independent individuals and organizations are insufficient. If the task can be solved at the local level as effectively as at the national level, the preference should be given to the local level. This principle works not only for governments, but also for all those in power: parties, corporations, trade unions, leaders of political movements, large business and banking structures.

The subsidiarity principle is based on the autonomy of the individual and their self-esteem. All forms of society - from the family to international bodies - must serve the individual. It is also followed by the fact that the source of the political power is the people. At the same time, the personalism states that people by their nature feel the necessity to communicate and want to be members of the basic units of society, such as the family, the parish, the neighborhood, the professional community, the volunteer organization. These cells act as intermediaries between a person and larger structures and, thus, give them real power. This scheme is reproduced at the level of medium and large public structures. This leads to the conclusion that the delegation of power to higher levels of government should be carried out only if it is really needed. In particular, the state can use its power only to the extent, necessary for the common good.

From an ethical point of view, the subsidiarity obliges the state and society to create conditions for the full development of the individual, including the provision of socio-economic human rights and security (Nazarova et al., 2019). The state is obliged to respect the independence of individuals and organizations, but, at the same time, it should promote the establishment of links between them. Even though it has no right to impose restrictions on the fair demands of individuals, but it must protect some members of society from the harm, connected with the private interests of others.

However, the subsidiarity not only recognizes the limitations of the central government, but also suggests a methodology for determining the scope of local government powers. In 1985, the European Charter of Local Self-Government (1985), going from the subsidiarity principle, assigned local administrations to solve all tasks, except those that they can't overcome. Thus, Article 4, paragraphs 3, 4, 5 and 6 of the Charter states:

Public powers are performed mainly by those authorities which are the closest to the citizens. The transfer of any function of any power body to another authority should be carried out taking into account the scope and nature of the specific task, as well as the requirements of the efficiency and economy", "As a rule, powers, granted to local governments, should be complete and exclusive. They may be questioned or restricted by any other central or regional authority only within the limits, established by law", "When delegating powers to any central or regional 
authority, local governments should have the right to adapt their powers to local conditions as much as possible"," It is necessary to consult with local governments as much as possible in a timely manner, especially in the process of planning and decision-making that affect them directly.

In 1986, the Common European Act divided the powers on the environment issues between the EU and its member countries in accordance with the principle of the subsidiarity. Together with the growth of concerns about the European centralization, the subsidiarity became increasingly attractive as a deterrent factor. In 1992, the Maastricht Treaty limited all EU powers to those areas where action by individual countries was insufficient.

These articles were further developed in the amendments to the Treaty on the establishment of the EU. According to the current version of this document, in areas which do not fall within its exclusive competence, the European Community acts in accordance with the principle of the subsidiarity only if the objectives of the supposed action can't be sufficiently achieved by the Member States and therefore, can be achieved more successfully by the EU.

The subsidiarity in relation to individual states in the world community and in the EU means that public authority in the world community does not aim to limit the scope of public authority of the individual political community (i.e. the state), much less to take its place. On the contrary, its aim is to create a global system, in which the public authorities of each political community, its citizens and their associations at different levels have the opportunity to carry out their tasks, perform their duties and enjoy their rights on a more sustainable basis. Accordingly, in order to implement the principle of the subsidiarity in the European legislation, legal acts must meet two requirements. Firstly, the EU needs a basis for action. Secondly, the scale of its actions should be proportional to the necessity (Noyhauz, 2005). When substantiating the compliance of the suggested measures within the subsidiarity principle, several criteria are used:

- Closeness of government to citizens. Political decisions must be made at a level, which is as close to the population as possible;

- Sufficiency. Is it possible for the set goals to be achieved sufficiently at lower levels (including by the citizens themselves);

- Benefit. Will solving the problem at a higher level be more efficient or profitable.

The newest stage in the development of the local self-government in Europe was based on the subsidiarity principle. At the end of the XX century in most European countries important structural, functional and organizational reforms of the system of local government were made. These reforms were aimed at redistributing functional relations between local, 
regional and central governments. They were carried out simultaneously with structural reforms and are linked closely to such concepts as "centralization", "decentralization" and "deconcentration".

Their result was the expansion of the competence of regional and local authorities, i.e. the decentralization of management, which means the transfer of certain powers by the central government to local governments (transfer of decision-making rights to bodies that are not hierarchically subordinated to central authorities and are often elected by the interested citizens).

The decentralization may be accompanied by the deconcentration - the transfer of power from the central level officials to the local level officials, appointed by the central government (organizational technique, which lies in the transfer of important decision-making rights to central government officials, appointed at various administrative districts or public services). There are vertical and horizontal deconcentration. Within the vertical deconcentration, all powers to represent the interests of the central government at the local level are transferred to one governmental official (prefect, commissioner, etc.), and horizontal deconcentration involves the division of responsibilities between several centers of government at the local level on a sectoral basis.

At the same time, it should be kept in mind that the democracy of the political system as a whole is not always directly linked to the level of the decentralization and deconcentration. In democracies, the necessity to decentralize the power may exist not because of democratic principles, some of which are better provided centrally, but because of administrative factors. And in countries where there are no established democratic traditions and the formally existing system of local government does not correspond to the real mechanism of the local government, the decentralization can even reduce the level of democracy in local governments. As the powers, delegated by the central government, are usually aimed at satisfying corporate interests of local elites (Assembly of European Regions, 2015).

Therefore, the excessive decentralization and autonomy of local authorities can't be understood as an absolute benefit from the point of view of democracy. The centralization of power also has a certain positive significance, it provides the benefits of a one government, free from local political disputes and prevents, as noted "an abuse of power by rural tyrants" (Brown et al., 1998). In some cases, the centralization means better coordination of local services and lower costs of services provided by local authorities. Thus, in carrying out reforms in European countries, decentralization and centralization are not seen as diametrically opposed concepts of the local government. The main problem in carrying out reforms is not to choose between decentralization and centralization, but to establish the necessary and appropriate balance between them. This balance should 
correspond adequately to the real socio-economic and political conditions of a particular country.

Foreign experience of the local self-government allows us to identify the following trends in its development:

- While maintaining the leading role of the representative bodies of the local self-government (councils) in resolving local affairs, the importance of the executive apparatus is increasing gradually and the influence of municipal officials is growing. This indicates the strengthening of professionalism of the municipal administration. Strengthening of executive bodies can take various forms. In particular, in determining the structure and status of local selfgovernment bodies, an increasing amount of authority's rights is assigned to executive bodies by the law. The representative bodies transfer part of their functions to executive bodies voluntarily (temporarily or on a permanent basis).

- The material and financial foundations of the local self-government are being strengthened. Each community has its own municipal (communal) property, which is necessary for the functioning of vital communal services. Municipalities use economic management methods widely - local taxes, licensing, signing contracts for performance of the municipal functions with private firms, etc.

- All this contributes to increasing the revenue part of local budgets, the development of the municipal economy and the stimulation of the entrepreneurial activity (Bantash et al., 2020). At the same time, in many countries (especially in the "post-Soviet" ones) the problem of forming a sufficient financial basis for the local self-government remains acute.

- The functions of local self-government bodies are changing significantly. This happens due to the following factors: first, there come new functions, the implementation of which was not necessary at the local level before (for example, the environmental ones) and which are now delegated to local governments by the state; secondly, some of the functions that were previously traditionally performed by local governments are transferred to private companies or public associations, bodies of self-organization of the population (for example, cleaning and recycling); third, the role of local governments in addressing social issues is declining.

Urbanization processes and demographic changes help, on the one hand, to reduce the number of rural settlements and to increase the number of urban ones, and, on the other, to deep an urban crisis (the growth of the suburbs leads to the movement of industry and social services from the city center to the periphery and, as a result, the mass relocation of the "middle class" to the suburbs). 
Sergiy Kvitka, Yevgeniy Borodin, Volodymyr Yemelyanov, Mykhailo Moskalets y Viktoriia Zubchenko

Urbanization gives rise to various agglomerations (metropolitan areas), which are a unity of the city itself, its suburbs and the surrounding small towns and villages, which are economically interconnected. There are many different, independent municipal management systems within these agglomerations, and the lack of coordinating bodies makes it difficult to follow a coherent policy within the agglomeration.

The absence of an approach to the agglomeration as a single whole causes the phenomena of territorial mismatch of resources, needs and free consumption. The first phenomenon is connected with the fact that local governments of those communities that are within the agglomeration try to provide the widest possible range of services, which leads to the irrational use of resources (the cost of services increases with the reduction of the number of residents, whom they are provided to).

The phenomenon of free consumption is that certain services are used by those for whom they are not directly targeted to and who do not pay for them. In particular, the inhabitants of suburbs (which are independent municipalities) use some services that the city provides to its residents.

Many municipal services (environmental protection, fire and police services, etc.) cannot be located within a separate agglomeration municipality, it is difficult to quantify and squeeze them into appropriate territorial boundaries in order to exclude outsiders living in other municipal agglomerations from the users of these services.

A steady trend in the development of the local self-government in Europe is the consolidation of administrative-territorial units, the reduction of the number of local authorities, the creation of various regional forms of government. These processes are aimed at forming a sufficient territorial, demographic, material and financial base for the maintenance of modern utilities and other municipal services.

For example, in Italy, according to the Law on the Organization of Local Autonomies, new communes can be created with the presence of at least 10,000 inhabitants, and provinces with 200,000 inhabitants. Significant financial incentives are provided for the unification and subsequent merger of communes with a population of less than 5,000 inhabitants or their accession to larger communes. Radical measures, aimed at the reduction of the number of communes, were used once in Sweden, Belgium, Denmark, Germany and other European countries. For example, in Sweden the number of communes was reduced from 848 to 288, in Belgium - from 2359 to 589.

At the same time, the number of grassroots self-governing units (communes) in some European countries still remains to be quite big: in France - 36,757; Germany - 8,500; Italy - 8,090; Spain - 8,056; Greece 5,750 (OECD, 2020). 
In some European countries (post-Yugoslav states) reverse processes take place, there communes are divided. This happens as the existing communes are too big. For example, in Slovenia, the average commune has an area of 321 square $\mathrm{kms}$ and a population of about 31 thousand inhabitants, in Macedonia the average size of the municipality is 850 square $\mathrm{kms}$ and the population exceeds 60 thousand people.

In many countries, the solution to the problem of forming a proper material basis for the local self-government is seen not in the consolidation of communes, but in the development of cooperation between individual communes (cooperative approach). Such cooperation is carried out through the signing the contractual agreements on the provision of services and fulfilling joint activities in certain areas by different bodies and levels of the local government (Regional Policy of the European Union, 2018).

Municipalities may enter the contractual relationships with other municipalities or regional authorities in different spheres, such as construction, fire safety, civil defense, health care, disaster management, and so on. There is a practice of creating a confederation of cities, which perform those functions that are beyond the power of the territorial communities of individual cities (Kvitka et al., 2020).

\section{Conclusion}

The legal principle of the subsidiarity is one of the most important principles of power institutions' organization. This principle is connected directly to the local self-government. The basic idea of this principle is that the central and regional authorities should interfere in activities of local self-government bodies only to some extent when the territorial community cannot meet its diverse needs by itself.

According to this principle, the distribution of powers between the bodies of different territorial levels should be carried out in such a way that, on the one hand, to be as close as possible to the citizen in the decision-making process, on the other hand, this level should have organizational, material and financial resources to provide the necessary volume and quality of social services, which are supplied to the population in accordance with national standards

The implementation of this principle includes two important aspects. On the one hand, the subsidiarity presupposes that a higher territorial authority can interfere the activity of a lower-level government only to such extent where the latter one demonstrated its weakness. That is, the subsidiarity in this sense is based on the principle of non-interference of state power or local government of a higher territorial level in solving issues of the local importance. On the other hand, the subsidiarity implies 
explicitly that higher-level authorities not only have the right, but they must interfere in the sphere of lower-level authorities' power. At the same time, this intervention does not mean substitution, but a certain type of assistance that encourages and empowers the grassroots.

Thus, in accordance with the subsidiarity principle, the transfer of powers from lower-level authorities to higher-level authorities is permitted only to the extent that those powers themselves can be better fulfilled at higher levels. At the same time, the idea that these powers should be performed at a level, which is as close to the citizen as possible, remains unchanged.

Based on the analysis of the relevant articles of the European Charter of Local Self-Government, the principle of the subsidiarity can be studied in its legal and political meanings.

Thus, the legal significance of the subsidiarity characterizes this principle as a certain formula for the division of powers in legislative acts, according to which the lowest level of government receives such powers that the subsequent territorial level of government can't perform more effectively. This division of powers allows, on the one hand, bringing the decisionmaking process as close as possible to the citizen, on the other - this level must have the appropriate resources. At the same time, the priority of the grassroots level in the distribution of powers should prevent any attempts of territorial organization of power to centralize the power in the system.

The political significance of the subsidiarity principle lies in the fact that it is a kind of tool that should ensure the performance of powers as close as possible to the citizen. These powers are revoked from the state and are transferred only to those authorities that work under the control of elected representatives. Thus, the subsidiarity principle becomes a barrier to the excessive centralization of power by the state body and to the separation of power from the people.

\section{Bibliographic References}

ASSEMBLY OF EUROPEAN REGIONS. 2015. From Subsidiarity to Success: The Impact of Decentralisation on Economic Growth Part 1-2: Creating a Decentralisation Index. A study commissioned by the Assembly of European Regions (AER).

BANTASH, Anastasiia; KOVAL, Viktor; BASHYNSKA, Maryna; KOZLOVTSEVA, Valentyna. 2020. "Balanced territorial economic development in the conditions of providing stability of human resources management” In: Economics. Ecology. Socium. Vol. 4, No. 3, pp. 58-66. 
BATANOV, Oleksandr Vasylovych; KRAVCHENKO, Viktor Vitaliiovych; PRYKHODJKO, Khrystyna Viktorivna. 2014. "Participatory democracy in local government system: problems of legal regulation" In: Public Administration Aspects. Vol. 2, No. 9-10, pp. 12-28.

BROWN, Lionel Neville; BELL, John; GALABERT, Jean-Michel. 1998. French administrative law. Clarendon Press, UK. Oxford, England.

DECENTRALIZATION IN UKRAINE. 2020. Available online. In: https:// decentralization.gov.ua. Consultation date: 14/05/2020.

EUROPEAN CHARTER OF LOCAL SELF-GOVERNMENT. 1985. Available online. In: https://rm.coe.int/168007ao88. Consultation date: 14/05/2020.

HRUBAS, Viktoriya Viktorivna. 2015. The principle of subsidiarity in decentralization process. Grani, Vol. 19, No. 1, pp. 17-23. Available online. In: https://doi.org/10.15421/1716003. Consultation date: 14/05/2020.

KOVAL, Viktor; MYKHNO, Inessal ANTONOVA, Liudmyla; PLEKHANOV, Dmytro; BONDAR, Victoria. 2019. "Analysis of environmental factors' effect on the development of tourism” In: Journal of Geology, Geography and Geoecology. Vol. 28, No. 3, pp. 445-456.

KOVAL, Viktor; SLOBODIANIUK, Olga; YANKOVYI, Volodimer. 2018. "Production forecasting and evaluation of investments using Allen twofactor production function" In: Baltic Journal of Economic Studies. Vol. 4, No.1, pp. 219-226.

KVITKA, Sergiy. 2015. "The principle of subsidiarity and decentralization in Ukraine" In: Public Administration Aspects. Vol. 3, No. 4, pp. 28-35.

KVITKA, Sergiy; BORODIN, Yevgeniy; YEMELYANOV, Volodymer; IVASHOVA, Liudmyla; BOCHAROV, Oleksii. 2020. "The foresight of national economy's digital development" In: Revista inclusiones. Vol. 7, special number, pp. 112-125.

MLED. 2020. Ukraine municipal local economic development program. Available online. In: http://www.mled.org.ua/ukr/materials/ publications. Consultation date: 14/05/2020.

NAZAROVA, Karina; HORDOPOLOV, Volodimir; KOPOTIIENKO, Tetiana; MINIAILO, Viktoriia; KOVAL, Viktor; DIACHENKO, Yuliia. 2019. "Audit in the state economic security system. Management Theory and Studies for Rural Business and Infrastructure Development”. Vol. 41, No. 3, pp. 419-430. 
Sergiy Kvitka, Yevgeniy Borodin, Volodymyr Yemelyanov, Mykhailo Moskalets y Viktoriia Zubchenko

NOYHAUZ, Norbert. 2005. Tsennosti hristianskoy demokratii (Values of Christian Democracy). - M. Respublika, RU. Moscow, Russia. (In Russian).

OECD. 2020. Regional Statistics. Available online. In: www.oecd.org. Consultation date: 14/05/2020.

POPE PIE. 1931. Encyclique Quadragesimo anno. L'École sociale populaire. Montréal, Canada.

POPE LEO XIII. 1891. Rundschreiben unseres Heiligsten Vaters Leo XIII. (...) über die Arbeiterfrage: (15. Mai 1891: Rerum novarum") = Sanctissimi Domini nostri Leonis divina providentia papae XIII. Litterae encyclicae de conditione opificum. Freiburg i.B: Herdersche Verlagshandlung. Roma, Vatican (in Latin).

POPOVA, Olga L; KOVAL, Viktor V; MIKHNO, Inesa S; TARASOV, Igor V; ASAULENKO, Natalya V; FILIPISHYNA, Liliya M. 2020. "Assessments of national tourism development in terms of sustainability and inclusiveness" In: Journal of Geology, Geography and Geoecology. Vol. 29, No. 2, pp. 377-386.

REGIONAL POLICY OF THE EUROPEAN UNION. 2018. History and Modernity European Integration: step by step. Fund «Yevropa XXI». Available online. In: http://old.europexxi.kiev. ua/ukrainian/program/ zmi/book3/o36.html. Consultation date: 14/05/2020 (in Ukrainian).

YANKOVYI, Oleksandr; KOVAL, Viktor; TROKHYMETS, Olena; KARPENKO, Maryna; MATSKEVICH, Yuliia. 2020. "Economic assessment of investment on the basis of production functions" In: Turismo: Estudos \& Práticas. Available online. In: http://natal.uern.br/periodicos/index. $\mathrm{php} / \mathrm{RTEP} /$ article/view/1310. Consultation date: 12/03/2020. 

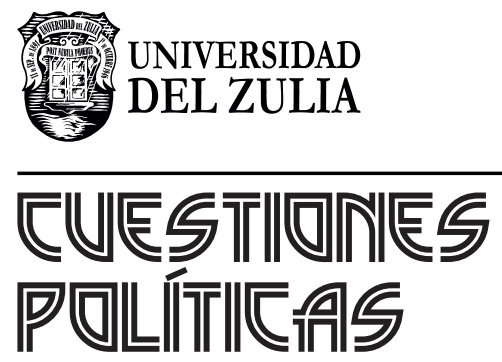

Vol.39 No 68

Esta revista fue editada en formato digital y publicada en enero de 2021, por el Fondo Editorial Serbiluz, Universidad del Zulia. Maracaibo-Venezuela 